\title{
ASSESSMENT OF ICHTHYOFAUNAL DAMAGE CAUSED BY INAPPROPRIATE HUMAN ARRANGEMENT OF THE NERETVA RIVER: CASE EXPERT EXAMINATION
}

\author{
Lejla Šatrovićc ${ }^{*}$, Edin Šatrović ${ }^{1}$
}

${ }^{1}$ Department of Veterinary State and Forensic Medicine

*Corresponding author:

Lejla Šatrović, MS, Senior Assistant Department of Veterinary State and

Forensic Medicine

Veterinary Faculty, University of

Sarajevo

Zmaja od Bosne 90

Sarajevo/Bosnia and Herzegovina

Phone: +38733729127

ORCID: 0000-0001-5962-6794

E-mail: lejla.krkalic@vfs.unsa.ba

\section{Original Submission:}

26 October 2020

Revised Submission:

30 November 2020

Accepted:

14 December 2020

\section{ABSTRACT}

The Department of Veterinary State and Forensic Medicine of the Faculty of Veterinary Medicine, University of Sarajevo, received a request for ichthyofaunal damage assessment in the fishing area of rivers, tributaries and lakes in the municipality of Konjic. The damage was caused by cleaning activities, removal of sediment from the riverbed and damage repair activities on the banks of the upper course of the Neretva River, which was carried out with certain irregularities that are not in accordance with the granted permit. Such irresponsible human activities inevitably have an impact on the living world of the aquatic ecosystem and often cause long-term harmful consequences. Through the presentation of this case, our main goal is to present the different types of harmful consequences resulting from such activities as well as the methodology of their calculation. In addition, the paper also points to violations of certain laws and bylaws governing this segment.

Keywords: Ichthyofauna, Neretva, direct damage, indirect damage, assessment 


\section{INTRODUCTION}

Bosnia and Herzegovina $(\mathrm{B} \& \mathrm{H})$ has significant water resources, which are one of the important factors of general economic development. Based on the consideration of its natural resources, $\mathrm{B} \& \mathrm{H}$ has significant potential for aquaculture, especially for the production of freshwater fish species. In addition, existing resources also provide excellent conditions for sport fishing and fishing-based tourism (Hamzić, 2003).

The Neretva River is one of the longest watercourses in B\&H (225 kilometers $(\mathrm{km})$ ), and in terms of water richness it only lags behind the Drina River. Neretva springs at an altitude of 1.095 meters $(\mathrm{m})$ below the mountains Zelengora and Lebršnik in B\&H, through which it flows for $203 \mathrm{~km}$, to the last $22 \mathrm{~km}$ of flow through Croatia before reaching the Adriatic Sea (Muhamedagić et al., 2019).

The fauna of the Neretva River is characterized by a significant richness and diversity of species, among which a special place is occupied by those endemic, narrowly distributed endangered species (soft-muzzled trout (lat. Salmo obtusirostris) and marble trout (lat. Salmo marmoratus) (Mrakovčić et al., 2006; Škrijelj et al., 2013). The negative human impact on freshwater ecosystems has become very pronounced in $\mathrm{B} \& \mathrm{H}$ in the last fifty years. The number of fish populations in the Neretva River is significantly affected by constant negative human actions on the river and its coastal area. One of the most harmful interventions on the waters in the Neretva basin is the construction of dams (Muhamedagić et al., 2008). The negative impacts of these facilities are multiple, such as changes in environmental conditions, changes in biodiversity and constant fluctuations in water levels (Riđanović et al., 2014). As a result of the dams built on the Neretva River due to changes in physico-chemical water parameters, the destruction of suitable habitats and preventing fish migration during spawning, certain parts of this river became cyprinid zones and the number of salmonids in the upper course of the Neretva River has decreased to the limits of extinction (Muhamedagić et al., 2008). The complex of various interventions by which man daily disrupts natural ecological processes and the diversity of ichthyofauna also includes the exploitation of forest complexes and the creation of erosive areas, road construction and formation of settlements along rivers and river valleys, wastewater and other facilities built along rivers, unregulated garbage dumps, gravel exploitation, landscaping, removal of stumps, etc. All these activities lead to various forms of physical, chemical and organic water pollution, which adversely affects the living organisms of this ecosystem. Uncontrolled and unplanned introduction of fish species, poaching and inadequate protection of ichthyofauna only complete the spectrum of various negative human effects on this precious natural resource (Muhamedagić et al., 2019).

This paper aims to present the case of a legally approved procedure of coastal management of the Neretva River, which due to certain irregularities (time and intensity of works, abuse of works for the purpose of gravel exploitation, etc.) caused various types of damage in this fishing area. The Department of Veterinary State and Forensic Medicine of the Faculty of Veterinary Medicine, University of Sarajevo received a request for damage assessment in the fishing area of rivers, tributaries and lakes of the municipality of Konjic, caused by cleaning activities, sediment removal from the riverbed and repair of damage on the banks of the upper Neretva River sent by a local Association of Sport Fishermen. The damage assessment was performed in November 2011. 


\section{MATERIAL AND METHODS}

\section{File and documentation review}

The material used in this expertise contained inspection service records, statements of fish guards, original video and photo documentation and other relevant files submitted by the Association of Sport Fishermen. A review of the same revealed the following:

- the Agency for the Water Area of the Adriatic Basin Mostar, based on the tender documentation, signed a contract for the execution of works with the contractor. Upon completion of the tender procedure, in October 2011 the contractor started performing works on the banks of the upper course of the river Neretva, which included cleaning activities, removal of sediment from the riverbed and repair of damages;

- the works were performed by using heavy construction machines, which led to significant changes in the riverbed, resulting in a negative impact on the living world of this aquatic ecosystem. The works were carried out to such an extent that they directly endangered the survival of the fish stock in such a way that the great turbidity caused the death of the fish due to suffocation (impossibility of fish breathing due to mechanical clogging of the gills with sludge and mud);

- the works were performed during the prohibition of fishing (October and November) in fishing areas that were stocked in April and May of the same year (restocking was performed twice, with a total of 1.000 kilograms $(\mathrm{kg})$ of brown trout (lat. Salmo trutta fario);

- the works were carried out with considerable intensity so was it noticed in November that the Neretva riverbed from the mouth of Lađanica to Kovnik-Pločara had been changed, i.e. the riverbed was moved from the right along the left bank. The workplace was about $600 \mathrm{~m}$ long and over 100 $\mathrm{m}$ wide. Work from the mouth of the Lađanica River continues upstream towards a place called Glavica-Ravne.

\section{Damage calculation methodology}

The calculation of the incurred damages was done in accordance with the relevant laws and bylaws. In order to be able to assess in the most adequate way and as accurately as possible the caused material damage, it is first necessary to give a definition of damage. Damage represents the reduction of someone's property (ordinary damage) and the prevention of its increase (lost benefit), and the infliction of physical or mental pain or fear (nonmaterial damage). Guilt exists in the case of intentionally or negligently caused damage (Law on Obligations („Official Gazette of the Federation of B\&H", No. 29/03). In the concept of this disputed case, when it comes to damages related to free-water fish, in the total damage calculation methodology it is necessary to take into account direct damages and indirect damages incurred at the site of the works and downstream.

Direct damage caused by activities on cleaning, removal of sediments from the riverbed and repair of damage on the banks of the upper course of the Neretva River is a loss due to the death of fish. Damage, in terms of the relevant bylaws governing this aspect, means damage caused to adult and juvenile fish. Adult fish are fish that have reached their consumption weight (4 pieces in $\mathrm{kg}$ ), while the term juvenile fish means younger fish in the breeding or fattening phase (Regulation on determining the amount of compensation for damage caused to fish stocks ("Official Gazette of the Federation of B\&H", No. 63/05). To calculate the mentioned harmful consequences, it is necessary to have data on the fish population 
and its density, i.e. the qualitative-quantitative structure of ichthyopopulation in this part of the Neretva River which is shown in Table 1.

Table 1 Comparative-synthetic presentation of the biopotential of the fish stock of the Neretva River before Konjic (area: 80 ha; amount kg / ha: 8.5) (Sofradžija et al., 2003)

\begin{tabular}{|c|c|}
\hline Fish species & $\begin{array}{c}\text { Participation in mass indicators of basic fund } \\
(\mathbf{\%})\end{array}$ \\
\hline $\begin{array}{c}\text { Brown trout } \\
\text { (lat. Salmo trutta fario) }\end{array}$ & 82.33 \\
\hline $\begin{array}{c}\text { Soft-muzzled trout } \\
\text { (lat. Salmo obtusirostris) }\end{array}$ & 10.21 \\
\hline $\begin{array}{c}\text { European grayling } \\
\text { (lat. Thymallus thymallus) }\end{array}$ & 5.32 \\
\hline $\begin{array}{c}\text { European chub } \\
\text { (lat. Squalius cephalus) }\end{array}$ & 2.04 \\
\hline $\begin{array}{c}\text { Eurasian minnow } \\
\text { (lat. Phoxinus phoxinus) }\end{array}$ & 0.1 \\
\hline Total & $\mathbf{1 0 0}$ \\
\hline
\end{tabular}

Analysis of an ichthyosample in the Neretva River before Konjic revealed the presence of five fish species belonging to three families. Brown trout (lat. Salmo trutta fario) and soft- muzzled trout (lat. Salmo obtusirostris) are species from the family Salmonidae. The family Thymallidae is represented by European grayling (lat. Thymallus thymallus). From the family Ciprinidae, two species have been registered: European chub (lat. Squalius cephalus) and European minnow (lat. Phoxinus phoxinus).

Ascan be seen from Table 1, the analysis of fish stock density revealed that there was approximately 8.5 $\mathrm{kg}$ of fish per hectare (ha) of water surface $(\mathrm{kg} / \mathrm{ha})$. According to the mass percentage of participation in the mixed fish settlement, the dominant place is occupied by salmonid and thymallid species $(97.86 \%)$. Of these species, brown trout participate with $82.33 \%$, soft-muzzled trout with $10.21 \%$ and European grayling with $5.32 \%$. Cyprinid species have the lowest mass fraction of $2.14 \%$, of which European chub makes up 2.04\%, and Eurasian minnow $0.10 \%$.

Based on the presented indicators, the stock of brown trout was estimated at 2.934 individuals, softmuzzled trout 134 specimens, European grayling 134 specimens and European chub 134 specimens (Table 2). Of the total fish stock population, 50\% are spawning females. On average, one female lays 1500 eggs, of which hatchability is $2 \%$. 
Table 2 Quantitative presentation of the fish population showing the number of females in the upper course of the Neretva River (Sofradžija et al., 2003)

\begin{tabular}{|c|c|c|c|}
\hline Fish species & Total number & Females & Amount of eggs \\
\hline $\begin{array}{c}\text { Brown trout } \\
\text { (lat. Salmo trutta fario) }\end{array}$ & 2934 & 1467 & 2200500 \\
\hline $\begin{array}{c}\text { Soft-muzzled trout } \\
\text { (lat. Salmo obtusirostris) }\end{array}$ & 134 & 67 & 100500 \\
\hline $\begin{array}{c}\text { European grayling } \\
\text { (lat. Thymallus thymallus) }\end{array}$ & 134 & 67 & 100500 \\
\hline $\begin{array}{c}\text { European chub } \\
\text { (lat. Squalius cephalus) }\end{array}$ & 134 & 67 & 100500 \\
\hline Total & $\mathbf{3 3 3 6}$ & $\mathbf{1 6 6 8}$ & $\mathbf{2 5 0 2} \mathbf{0 0 0}$ \\
\hline
\end{tabular}

\section{RESULTS}

Direct damage due to adult fish mortality is calculated in accordance with the Regulation on determining the amount of compensation for damage caused to the fish stocks ("Official Gazette of the Federation of B\&H", No. 63/05) and the Law on Freshwater Fisheries ("Official Gazette of the Federation of B\&H”No. 64/04).

The analysis of fish stock density revealed that there were a total of about $8.5 \mathrm{~kg}$ of fish per hectare (ha) of water surface $(\mathrm{kg} / \mathrm{ha})$ (Table 1$)$, i.e. for: brown trout $6.99 \mathrm{~kg} / \mathrm{ha}$; soft- muzzled trout $0.87 \mathrm{~kg} / \mathrm{ha}$; European grayling $0.45 \mathrm{~kg} / \mathrm{ha}$; European chub $0.17 \mathrm{~kg} / \mathrm{ha}$. As can be seen from the documentation, the works took place in an area $600 \mathrm{~m}$ long and over $100 \mathrm{~m}$ wide, so that the affected area of the Neretva watercourse was 6 ha. This would mean that the values of destroyed fish expressed in $\mathrm{kg}$ should be increased six times, giving the following values: brown trout $41.94 \mathrm{~kg}$, soft-muzzled trout $5.22 \mathrm{~kg}$, European grayling 2.7 $\mathrm{kg}$ and European chub $1.02 \mathrm{~kg}$.

The above - mentioned Regulation, Articles (Art.) 3 and 5, prescribes the amount of compensation for brown trout, soft-muzzled trout and European grayling (Group II) and European chub (Group $\mathrm{V}$ ) with the stated price of $1 \mathrm{~kg}$ of fish species of group II in the amount of 12.00 convertible marks (KM) and 5.00 KM for species belonging to group V. According to this Regulation, Art.7, the amount of compensation for damage should be increased 2 times for adult fish and 5 times for juvenile fish. The calculated direct damage in the affected area due to adult fish mortality according to these guidelines is shown in Table 3. 
Table 3 Overview of direct damage to fish stocks on an area of 6 ha

\begin{tabular}{cc}
\hline Fish species & Total direct damages BAM \\
\hline $\begin{array}{c}\text { Brown trout } \\
\text { (lat. Salmo trutta fario) }\end{array}$ & $1.006,56$ BAM \\
\hline $\begin{array}{c}\text { Soft-muzzled trout } \\
\text { (lat. Salmo obtusirostris) }\end{array}$ & 125,28 BAM \\
\hline $\begin{array}{c}\text { European grayling } \\
\text { (lat. Thymallus thymallus) }\end{array}$ & 64,80 BAM \\
\hline $\begin{array}{c}\text { European chub } \\
\text { (lat. Squalius cephalus) }\end{array}$ & 10,20 BAM \\
\hline Total & $\mathbf{1 . 2 0 6 , 8 4 ~ B A M ~}$ \\
\hline
\end{tabular}

BAM is the monetary currency of Bosnia and Herzegovina, $1 \mathrm{BAM}=1.95583$ EUR.

Direct damages due to the mortality of juvenile fish (stocked fund) are determined in accordance with the submitted documentation from which the restocking activities are visible (restocking was performed with a total of $1000 \mathrm{~kg}$ of brown trout). Therefore, contractor's activities caused direct damage to $1000 \mathrm{~kg}$ of juvenile brown trout. According to the Regulation on determining the amount of compensation for damage caused to fish stocks ("Official Gazette of the Federation of B\&H”, No. 63/05), Art. 5 stated price for $1 \mathrm{~kg}$ of fish in the amount of 12 BAM, which means a total of 12000 BAM. According to Art. 7 of the same Regulation, which states whether the consequences arose from the actions referred to in Art. 46, paragraph 1, item 1. to 7. of the Law on Freshwater Fisheries, this amount should be increased 5 times for juvenile fish, so in the end the amount of damage would be 60000 BAM.

According to data obtained from the Association of Sport Fishermen, the turbidity of the lower course of the river from the work site was approximately $6 \mathrm{~km}$ long, which means that the affected part of the length is at least another 6 ha. Direct damages caused below the work site (downstream) are calculated by reducing the estimated damage by $20 \%$ for each additional ha of the area where the activities took place, as shown in Table 4.

The total caused direct damage is summarized in Table 5. 
Table 4 Damages inflicted downstream from the work site on the surface of the next 6 ha

\begin{tabular}{ccc}
\hline Hectars (ha) & Basic damage & $\mathbf{2 0 \%}$ reduction \\
\hline 7 th & $61.206,84$ BAM & $48.965,47$ BAM \\
\hline 8 th & $48.965,47$ BAM & $39.172,37$ BAM \\
\hline 9 th & $39.172,37$ BAM & $31.337,89$ BAM \\
\hline 10 th & $31.337,89$ BAM & $25.070,31$ BAM \\
\hline 11 th & $25.070,31$ BAM & $20.056,24$ BAM \\
\hline 12 th & $20.056,24$ BAM & $16.044,99$ BAM \\
\hline Total & & $\mathbf{1 8 0 . 6 4 7 , 2 7 ~ B A M}$ \\
\hline
\end{tabular}

BAM is the monetary currency of Bosnia and Herzegovina, 1BAM $=1.95583$ EUR.

Table 5 Total direct damages due to fish mortality at the site of work and downstream

\begin{tabular}{cl}
\hline Damage due to mortality of adult fish & $1.206,84$ BAM \\
\hline Damage due to mortality of juvenile - stocked fish & $60.000,00$ BAM \\
\hline Damage caused below the work site & $180.647,27$ BAM \\
\hline Total & $\mathbf{2 4 1 . 8 5 4 , 1 1 ~ B A M ~}$ \\
\hline
\end{tabular}

BAM is the monetary currency of Bosnia and Herzegovina, 1BAM $=1.95583$ EUR.

In addition to direct damage (damage caused by an immediate harmful act), it is necessary to point out significant indirect damages which occur as a result of that action. They are shown by damage to juvenile fish due to loss of natural spawning or so-called missed benefit according to the Law on Obligations (,Official Gazette of the Federation of B\&H", No. 29/03). Since the mentioned works caused direct damage to the fish stock on the area of 6 ha during the time when fishing was prohibited, which also means the spawning period, the natural spawning of fish was disabled. Of the total fish stock population, $50 \%$ are spawning females and on average, one female lays 1500 eggs, of which hatchability is $2 \%$. Table 2 shows the total number of fish populations as well as the number of females in the Neretva River before Konjic, and it follows that fish spawning and laying of 2502000 eggs is disabled because of the destruction of fish stocks in this area of the river. If we take into account an average hatchability of about $2 \%$, it would ultimately result in 50040 pieces of potential juvenile fish as direct damage in the works area and on an area of 6 ha.

A significant harmful consequence of the activities carried out is also the destruction of zoobenthos and phytobenthos. Zoobenthos (river invertebrates - aquatic insects, crustaceans, leeches, etc.) and phytobenthos (algae and other plant organisms) are the starting point for the development of 
aquatic vertebrates, primarily fish, and their saprobiological role implies their importance in assessing water quality (Dedić et al., 2018). Taking into account the characteristic bed and flow of the Neretva River in the upper course it is estimated that it takes at least five years to restore the previous condition. Therefore, it is necessary to intensify the revitalization of this flow of the Neretva River at least during this period. It is necessary to develop and implement a benthos revitalization program in this area of the Neretva with a part downstream (length about $6 \mathrm{~km}$ ) with competent experts who could provide a cost estimate.

The mentioned works, in order to reduce the fish stock, also caused indirect damages in the field of fishing economy, given that the reduction of fish stocks results in the absence of fishermen in the future until the rehabilitation of the fishing area., i.e. non-payment of permits and other activities (visits, promotion of the Municipality, catering, tourism, etc.). Such damages can be calculated by inspecting the records of various business entities. Competent experts should assess the negative consequences in the private and public sectors that arise from this.

\section{DISCUSSION AND CONCLUSIONS}

By writing this article, we want to acquaint the professional and wider readership with the negative consequences as well as the extent of damage to ichthyofauna that can occur during malfeasances in the execution of works on coastal landscaping. It often happens that the concessionaire performs such activities in an improper manner and primarily for the purpose of material enrichment (e.g. illegal exploitation of gravel), which is accompanied by the destruction of the integrity of aquatic ecosystems. In order to prevent such activities under the expression of legal actions, it is necessary to intensify supervision by inspection services during the planning and implementation of works. Only in this way it is possible to ensure strict observance of legally regulated principles and conditions under which it is possible to perform such and similar activities on rivers, i.e. fishing areas and thus minimize as much as possible the negative impact on the integrity of the living organisms in the aquatic ecosystem.

Through the presentation of this case, the aim of the authors was primarily to acquaint readers with the procedure and methodology of damage assessment that occurs in open waters due to inadequate coastal regulation. The second objective of this study was to point out violations of numerous legal acts that may arise from such actions.

The manner in which the activities of cleaning, removing sediment from the riverbed and repairing the damage on the banks of the upper Neretva River were carried out, led to violations of numerous laws and bylaws.

Based on the Law on Freshwater Fisheries ("Official Gazette of the Federation of B\&H”, No. 64/04) in Art. 35, paragraph 2, it is clearly indicated that all activities in the fishing water may be carried out under conditions which protect the fish stock and ensure the unimpeded migration and reproduction of fish. Paragraph 3 of the same Art. stipulates that the contractor, if he does not ensure the free migration of fish, is obliged to compensate the damage caused to the user of the fishing area and to adopt a program of revitalization of living communities and bring them into proper condition by ensuring continuous restoration of fish to maintain natural reproduction. Article 36 of the same Law prohibits the extraction of gravel, stones and stumps in natural fish hatcheries, and during spawning, it also prohibits other activities that interfere with natural 
spawning. Article 46 of the same Law states that in the fishing area and other fishing waters it is prohibited to pollute fishing water with harmful and dangerous substances that can change or worsen the established quality of water or part of fishing water and thus endanger the fish stock.

Pursuant to the Law on Environmental Protection ("Official Gazette of the Federation of B\&H", No. 33/03), Art. 14 stipulates that the natural flow, structure and conditions of the flow, riverbed and coastal areas may be changed only while ensuring the preservation of the natural balance of aquatic and semi-aquatic ecosystems and their functioning.

Based on the Law on Water Protection ("Official Gazette of the Federation of B\&H “, No. 33/03, 54/04) Art. 32, it is stated that the removal of materials, such as gravel, sand, etc., is permitted to the extent and in a manner that ensures that natural processes do not change significantly, that the natural balance of aquatic and semi-aquatic ecosystems is not disturbed and that the negative impact of water does not increase.

Pursuant to the Regulation on the organization and work of the fish guard service, the form and content of the identification template and the fish guard badge ("Official Gazette of the Federation of B\&H “, No. 63/05) in Art. 2, it is stated that the user of the fishing right is obliged to ensure the preservation and protection of the fish stock of fishing waters and zones, coastal areas and environment through well-organized and efficient work of the fisheries service in accordance with the fishing economic basis. In Art. 3 it is stated that the user organizes a fish guard service through which he protects the fishing area, natural spawning, protection and preservation of fish stocks, protection and preservation of the coastal area and the environment from destructive behavior of individuals and organizations.
Such activities also violate the provisions of the Convention on International Trade in Endangered Species of Wild Fauna and Flora (CITES), which is an international agreement aimed at preventing uncontrolled international trade and commercial exploitation of endangered species, maintaining ecological balance in populations of internationally traded species and assisting Member States in achieving sustainable trade (Krkalić et al., 2011). Bosnia and Herzegovina ratified this Convention in 2009 and thus undertook to draft legislation and protect endangered species of flora and fauna. Activities that disrupt the existing flora and fauna (soft-muzzled trout and marble trout as endemic species) complicate and prevent the listing of endangered species as well as the creation of quality laws and bylaws in this regard and thus the conservation of endemic species in $\mathrm{B} \& \mathrm{H}$.

Based on the presented analysis, we estimated the total direct damage $(241.854,11 \mathrm{KM})$ and listed the items that should be taken into account for the assessment of indirect damage. Pursuant to the Law on Freshwater Fisheries ("Official Gazette of the Federation of B\&H”, No. 64/04) in Part VIII - Penal Provisions, Art. 52 defines a money fine of 2000 to $8000 \mathrm{KM}$ for legal persons for the offenses referred to in paragraph 12 (if its activity causes the death of fish), 13 (builds or reconstructs a water management or other facility on fishing water) and 15 (in natural fish hatcheries extracts gravel, sand, stone and stumps and performs other actions that interfere with spawning, or organizes fishing). After an expert examination and a detailed analysis of this case, it is clear that the legal penalties for these activities are incomparably less than the actual damage caused by the contractor's activities (estimated amount of damage) and are not in accordance with the calculated damage obtained under the instructions of the Regulation on determining the amount of compensation for 
damage caused to fish stocks ("Official Gazette of the Federation of B\&H”, No. 63/05).

From this it follows that it is necessary to approach the systematic protection and improvement of ichthyoresources of the Neretva River, its tributaries and accumulation lakes. The measures to be taken can be divided into two categories: technical and administrative. Technical measures include all procedures and actions that directly affect the increase in the number of fish stocks and include restoration of fishing waters and the protection of waters from harmful interventions, erosion, wastewater and coastal usurpation. For the successful protection of fishing waters, it is necessary to establish quality cooperation with the competent municipal and cantonal services relevant to this segment. Administrative measures should regulate and prescribe the possibility of annual fishing, the number of annual fishing trips, permanent and temporary fishing bans and a number of other regulations that will enable the rational use of fish stocks and planned management of fishing waters.

\section{CONFLICT OF INTEREST}

The authors declare that they have no conflict of interest.

\section{REFERENCES}

Dedić A, Galić T, Stanić-Koštroman S, Škobić D, Lasić A, Hafner D. 2018. A biological water quality assessment based on Phytobenthos and Macro invertebrates at three stations on the river Neretva. Works of the Faculty of Forestry, University of Sarajevo 48 (2), 41-53.

Hamzić A. 2003. Akva kultura u Bosni i Hercegovini. Sarajevo, Bosna i Hercegovina: Coron's d.o.o.

Krkalić L, Šatrović E, Goletić T, Hadžiomerović Z, Mulabdić F. 2011. CITES - The Convention on International Trade in Endangered Species of Wild Fauna and Flora. Vet Žurnal RS, 11(1), 97-100.

Mrakovčić M, Brigić A, Buj I, Ćaleta M, Mustafić P, Zanella D. 2006. Red book of freshwater fish of Croatia. Zagreb, Croatia: Min. culture, SINP.

Muhamedagić S, Gjoen HM, Vegra M. 2008. Salmonids of the Neretva river basin-present state and suggested sustainable selection programme to protect and strengthen salmonid populations. Proceedings of the EIFAC symposium on iteractions between social, economic and ecologicak objectives on inland commercial and recriational fisheries and aquaculture. FAO, Turkey, 224-75.

Muhamedagić S, Pavličević J, Savić N. 2019. Composition of ichthyopopulations in the upper stream of the Neretva river, half a century after the construction of the first dam. Works of the Faculty of Agriculture and Food Sciencies, University of Sarajevo, 64(69), 135-45.
Riđanović S, Šarić M, Riđanović L. 2014. The impact of hydro power plants on oxygen regime and ichthyopopulations of freshwater ecosystems, in: EDZ, 28th International "Electrical Engineering Symposium”. EIS 2014.

Sofradžija A, Hadžiselimović R, Spahić M, Škrijelj R, Jažić A, Guzina N, et al. 2003. Ribarstveno-gospodarska osnova OSR "Konjic" - Konjic, UGSR "Glavatica" - Jablanica i UGSR "Neretva" - Mostar. Sarajevo, Bosna I Hercegovina: Centar za ihtiologiju i ribarstvo Prirodno-matematičkog fakulteta Univerziteta u Sarajevu.

Škrijelj R, Lelo S, Drešković N, Sofradžija A, TrožićBorovac S, Korjenić E, Lukić-Bilela L, Mitrašinović-Brulić M, Kotrošan D, Šljuka S, Gajević M, Karačić J. 2013. Red list of fauna of the Federation of Bosnia and Herzegovina. Federal Ministry of Environment and Tourism, Sarajevo.--Regulation on the organization and work of the fish guard service, the form and content of the identification template and the fish guard badge ("Official Gazette of the Federation of B\&H”, No. 63/05)

--- Regulation on determining the amount of compensation for damage caused to fish stocks ("Official Gazette of the Federation of B\&H”, No. 63/05).

--- Law on Freshwater Fisheries ("Official Gazette of the Federation of B\&H”, No. 64/04).

--- Law on Water Protection ("Official Gazette of the Federation of B\&H", No. 33/03, 54/04).

--- Law on Environmental Protection ("Official Gazette of the Federation of B\&H”, No. 33/03).

--- Law on Obligations ("Official Gazette of the Federation of B\&H”, No. 29/03). 


\section{PROCJENA ŠTETE NA IHTIOFAUNI UZROKOVANE NEPRIKLADNIM UREĐENJEM RIJEKE NERETVE: SLUČAJ VJEŠTAČENJA}

\section{SAŽETAK}

Katedri za sudsko i upravno veterinarstvo Veterinarskog fakulteta Univerziteta u Sarajevu upućen je zahtjev za procjenu štete u ribolovnom području rijeka, pritoka i jezera u općini Konjic. Šteta je nastala kao rezultat aktivnosti čišćenja, uklanjanja nanosa iz korita i sanacije oštećenja na obalama gornjeg toka rijeke Neretve, izvedenih uz određene nepravilnosti koje nisu u skladu sa dodijeljenom dozvolom. Ovakvi neodgovorni ljudski postupci neizbježno utječu na živi svijet vodenog eko sistema i često uzrokuju dugoročne štetne posljedice. Kroz prezentaciju ovog slučaja, naš glavni cilj je prikazati različite vrste štetnih posljedica koje proizlaze iz takvih aktivnosti, kao i metodologiju njihovog proračuna. Pored toga, rad također ukazuje na kršenje određenih zakona i podzakonskih akata koji uređuju ovaj segment.

Ključne riječi: Ihtiofauna, Neretva, direktna šteta, indirektna šteta, procjena 